\title{
PLASMA LIPID METABOLITES AND LIVER LIPID COMPONENTS IN BROILERS AT 21 DAYS OF AGE IN RESPONSE TO DIETARY DIFFERENT FIBER SOURCES
}

\author{
H.M. Safaa ${ }^{1,2}$, E. Jiménez-Moreno ${ }^{2}$, M. Frikha ${ }^{2}$, G.G. Mateos ${ }^{2}$ \\ 1- Departament of Animal Production, Faculty of Agriculture, Cairo University, 12613 Giza, Egypt, 2- \\ Departamento de Producción Animal, Universidad Politécnica de Madrid, 28040 Madrid, Spain \\ Corresponding author: H.M. Safaa (hosam.safaa@agr.cu.edu.eg)
}

\begin{abstract}
SUMMARY
One hundred twenty one-day-old female Ross 308 broilers were used to evaluate the impact of including oat hulls $(\mathrm{OH})$, sugar beet pulp (SBP), and pea hulls $(\mathrm{PH})$ at levels of 2.5, 5.0, and 7.5\% in the diet on lipid metabolism of broilers from hatch to $21 \mathrm{~d}$ of age. The $\mathrm{OH}$, SBP, and PH contained 0.7, 11.6, and 5.1\% soluble fiber and 70.6, 47.4, and $49.6 \%$ insoluble fiber, respectively. The control diet contained $1.6 \%$ crude fiber $(6.9 \%$ dietary fiber). The fiber sources were included in the experimental diets at the expense (wt/wt) of the control diet. Each treatment was replicated 6 times (a cage with 2 chicks). At 21 d of age, one chick per replicate was slaughtered and plasma lipid metabolites and liver lipid components were determined. At $21 \mathrm{~d}$ of age, the inclusion of fiber in the diet tended to reduce total cholesterol $(P=0.06)$ and to increase HDL cholesterol $(P=$ $0.06)$ in plasma and reduced lipid components of the liver including total lipids, triglycerides, and total cholesterol $(P<0.05)$. Type of fiber did not affect total lipids, triglycerides, and LDL cholesterol in the plasma or the relative weight (\% of $B W$ ) of the liver. Plasma HDL, however, was higher in birds fed $\mathrm{OH}$ than in birds fed PH or the control diet with birds fed SBP being intermediate $(P<0.01)$. An increase in the level of fiber in the diet from 0 to $7.5 \%$ tended to decrease triglycerides in the liver from 7.37 to $6.00 \mathrm{mg} / \mathrm{g}$ across treatments $(P$ $=0.08)$ but did not affect any of the other traits studied. It is concluded that the inclusion of fiber in the diet modified, in different ways, lipid metabolism in broilers at $21 d$ of age. Fiber sources differing widely in solubility and physicochemical properties had little impact on these traits. An increase in the level of fiber reduced lipid components in the liver at this age.
\end{abstract}

\section{Keywords: Broilers, dietary fiber, liver lipid components, plasma Lipid metabolites}

\section{INTRODUCTION}

It is well known that several dietary fibers decrease serum cholesterol concentrations in human (Anderson et al. 1990a,b; Slavin, 2008 and Sarmento and Ticiana, 2013), rats (Kahlon et al., 1993 and Wang et al., 1997) and broilers (Razdan et al., 1997; Yusrizal and Chen, 2003; Viveros et al., 2007 and Zhang et al., 2013). These effects on blood contents might be noted also for liver lipogenesis in broilers (Velasco et al., 2010) and animals (Delzenne et al. 2002). Moreover, Anderson et al. (1994) reported that dietary soluble fibers such as pectins reduced serum and liver cholesterol, however, insoluble fibers had little effects on these traits. Recently, Brownawell et al. (2012) and Slavin (2013) reported that soluble fibers are the most effective in lowering cholesterol concentrations and not all fibers are equal in terms of the types and extent of health benefits they provide.

There is a growing interest in evaluating the effects of fiber inclusion to poultry diets on lipid metabolism (Mohiti-Asli et al., 2012a and b). It has been reported that the inclusion of pectins from sugar beet pulp (SBP) in chicken diets reduced plasma lipid levels and may assist in overcoming high plasma lipid concentrations associated with reduced meal frequency (Pettersson and Aman, 1991; Pettersson and Razdan, 1993 and Razdan and Pettersson, 1994). Moreover, dietary fiber fractions from legume seeds has also been reported to be an important component that might reduce serum cholesterol levels (Uberoi et al., 1992). Pea (Pisum sativum L.) fiber was reported as hypocholesterolemic agent that alters postprandial lipaemia and lipoproteins in humans which attributed to long-term metabolic effects (Dubois et al., 1993 and Lairon, 1996) and pea hulls (PH) were considered as an ingredient in broiler diets (JiménezMoreno et al., 2011 and Frikha et al., 2013).

The hypothesis of this research was that the inclusion of moderate amounts of fiber into low fiber diets may play a role in lipid metabolism, and its effects may depend on type and level of inclusion of the fiber. In this respect, we hypothesized that increases in soluble fibrous fractions such as pectins from SBP to the diet, which are dispersible in water might affect lipid metabolism in broiler chickens. On the other hand, insoluble fibrous fractions, such as those present in oat hulls $(\mathrm{OH})$, might have no effect on lipid metabolism while, $\mathrm{PH}$ that contain mainly cellulose, hemicellulose and low pectin content, might have intermediate effect. Therefore, the aim of this study was to evaluate the effect of increasing levels of 3 fiber sources $(\mathrm{OH}, \mathrm{SBP}$ and $\mathrm{PH})$ with different physicochemical properties from 1 to $21 \mathrm{~d}$ of age on blood and liver lipid metabolism of broilers at $21 \mathrm{~d}$ of age. 


\section{MATERIALS AND METHODS}

Fiber sources and diets:

A batch of OH, a batch of SBP and a batch of PH were obtained from a commercial supplier and grounded using a hammer mill (Model 15303, Fritsch $\mathrm{GmbH}$, Rudolstadt, Germany) fitted with a 2-mm screen and analyzed for chemical composition, physical properties and geometric mean diameter (Table 1). The basal control diet was based on rice, soy protein concentrate and fish meal (Table 2) and contained 3,265 kcal $\mathrm{AME}_{\mathrm{n}} / \mathrm{kg}$ diet and $6.9 \%$ dietary fiber ( $1.6 \%$ crude fiber). The remaining experimental diets were manufactured by diluting (wt/wt) the control diet with $2.5,5.0$ or $7.5 \%$ of either OH, SBP or PH. All diets were fed in mash form and met or exceeded the nutritional recommendations of Fundación Española Desarrollo Nutrición Animal (2008) for broilers.

Table 1. Determined chemical composition (\%, as-fed basis), geometric mean diameter (GMD \pm GSD), water holding capacity $\left(\right.$ WHC \pm SD) and swelling capacity $(\mathrm{SWC}, \mathrm{mL} / \mathrm{g} \mathrm{DM})$ of fiber sources ${ }^{1}$

\begin{tabular}{|c|c|c|c|}
\hline Item & Oat hulls & Sugar beet pulp & Pea hulls \\
\hline \multicolumn{4}{|l|}{ Chemical analysis } \\
\hline Gross energy, kcal $/ \mathrm{kg}$ & 4,156 & 3,678 & 3,869 \\
\hline Dry matter & 93.6 & 91.4 & 90.3 \\
\hline Crude protein & 3.0 & 8.9 & 12.1 \\
\hline Starch & 9.2 & 1.0 & 8.9 \\
\hline Ether extract & 1.4 & 1.1 & 1.4 \\
\hline Total ash & 3.7 & 9.2 & 4.0 \\
\hline Crude fiber & 28.3 & 17.8 & 39.3 \\
\hline Total dietary fiber & 71.3 & 59.0 & 57.4 \\
\hline Insoluble dietary fiber & 70.6 & 47.4 & 49.6 \\
\hline Soluble dietary fiber & 0.7 & 11.6 & 5.1 \\
\hline Neutral detergent fiber & 70.2 & 34.2 & 47.0 \\
\hline Acid detergent fiber & 33.4 & 18.0 & 35.8 \\
\hline Acid detergent lignin & 3.7 & 1.8 & 1.1 \\
\hline \multicolumn{4}{|l|}{ Physical properties } \\
\hline \multicolumn{4}{|l|}{ Screen size, $\mu \mathrm{m}$} \\
\hline 1,250 & 31 & 266 & 214 \\
\hline 630 & 409 & 472 & 543 \\
\hline 315 & 353 & 152 & 155 \\
\hline 160 & 150 & 65 & 67 \\
\hline 80 & 50 & 40 & 17 \\
\hline$<40$ & 7 & 5 & 4 \\
\hline $\mathrm{GMD} \pm \mathrm{GSD}^{2}, \mu \mathrm{m}$ & $509 \pm 1.9$ & $796 \pm 2.1$ & $805 \pm 1.9$ \\
\hline $\mathrm{WHC} \pm \mathrm{SD}, \mathrm{L} / \mathrm{kg}$ dry matter & $3.93 \pm 0.051$ & $10.60 \pm 0.080$ & $5.54 \pm 0.031$ \\
\hline $\mathrm{SWC} \pm \mathrm{SD}, \mathrm{mL} / \mathrm{g}$ dry matter & $2.06 \pm 0.350$ & $6.18 \pm 0.778$ & $5.45 \pm 0.631$ \\
\hline
\end{tabular}

${ }^{\mathrm{T}}$ Analyzed in triplicate samples.

${ }^{2}$ Log normal standard deviation.

Experimental design and husbandry:

All procedures used in this research were approved by the Animal Ethics Committee of the Universidad Politécnica de Madrid and were in compliance with the Spanish guidelines for the care and use of animals in research (Boletín Oficial del Estado, 2007).

The experiment was conducted as a completely randomized design with 10 dietary treatments consisting of a negative control diet with a low fiber content and nine additional diets arranged factorially with 3 sources of fiber ( $\mathrm{OH}, \mathrm{SBP}$ and $\mathrm{PH})$ and three levels of fiber inclusion (2.5, 5.0 and 7.5\%). In total, 120 one-day-old female Ross 308 chicks with an initial BW of $47.8 \pm 3.3 \mathrm{~g}$ were housed in an environmentally controlled room and randomly distributed in groups of two in 60 battery cages (Avícola Grau, Madrid, Spain) equipped with 2 drinker cups and an open trough feeder. Room temperature was kept at $33^{\circ} \mathrm{C}$ during the first $3 \mathrm{~d}$ of life and then, it was reduced gradually according to age until reaching $24^{\circ} \mathrm{C}$ at $\mathrm{d} 21$. Chicks had free access to feed and water throughout the experiment and received a light program of $23 \mathrm{~h}$ light from $\mathrm{d} 1$ to 7 and $18 \mathrm{~h}$ light from $\mathrm{d} 8$ to 21 .

\section{Laboratory analyses:}

Fiber sources and diets were analyzed for total ash using a muffle furnace (method 942.05) and for nitrogen by Dumas (method 968.06) using a LECO analyzer (model FP-528, Leco Corporation, St. Joseph, MI) as described by AOAC International 
(2000). Dry matter (DM) was determined by ovendrying (method 6) and ether extract (EE) by Soxhlet fat analysis after $3 \mathrm{~N} \mathrm{HCl}$ acid hydrolysis (method 4.b) as described by Boletín Oficial del Estado (1995). Gross energy of all samples was measured with an isoperibol bomb calorimeter (model 356, Parr Instrument Company, Moline, IL). Neutral and acid detergent fiber of the tested fiber sources and experimental diets and acid detergent lignin $\mathrm{pH}$ were determined sequentially as described by Van Soest et al. (1991) and expressed on an ash-free basis. Starch content of such fiber sources and diets were measured by the amyloglucosidase/ $\alpha$-amylase (method 996.11; AOAC International, 2000). Particle size distribution and geometric mean diameter of the tested fiber sources and the experimental diets were determined in triplicate according to the methodology recommended by the American Society of Agricultural Engineers (1995). Water holding capacity of the tested fiber sources and the experimental diets were determined as indicated by Jiménez-Moreno et al. (2009). All the analyses were conducted in triplicate.

\section{Plasma lipid metabolites and liver lipid components:}

At the end of the experiment, one chick per cage, were selected at random, slaughtered and used for the studied traits at $21 \mathrm{~d}$ of age. Three $\mathrm{mL}$ blood samples from these slaughtered chicks were collected in heparinized tubes. Blood samples were centrifuged at $3,000 \mathrm{rpm} / \mathrm{min}$ for $10 \mathrm{~min}$. Clear plasma samples were separated into Eppendorf tubes and kept in the deep freezer at $-20^{\circ} \mathrm{C}$ until chemical analyses. In addition, livers were separated from the same slaughtered chicks used for blood samples. Total lipids were extracted and purified from liver samples according to the methodology described by Bligh and Dyer (1959). Briefly, $1 \mathrm{~g}$ from homogenized liver sample was collected in a sterile tube containing a mixture of $15 \mathrm{~mL}$ chloroform and methanol (2:1; $\mathrm{vol} / \mathrm{vol}$ ) and was shaken. Then, distilled water was used for washing the samples three times $(5 \mathrm{~mL}$ per each time) followed by centrifugation $(2,500$ $\mathrm{rpm} / \mathrm{min}$ for $10 \mathrm{~min}$ ). The aqueous methanol layer was filtered and the filtered aqueous layer was received in sterilized glass vial that was separated tightly. Then, the chloroform lipid extraction was transferred into a test tube for chemical analyses.

The biochemical analyses were conducted at the laboratory of biochemistry, Cairo University Research Park (CURP), Giza, Egypt. Total lipids were reacted with vanillin in the presence of sulfuric and phosphoric acid to produce complex color which was measured by spectrophotometer (Spectronic Helios Gamma UV-Vis, Serial no.: UVG-160414, wavelength range: 190-1100nm, Thermo Fisher Scientific, England) at $530 \mathrm{~nm}$ according to the method described by Knight et al. (1972). Triglycerides were determined colorimetrically according to Fossati and Prencipe (1982) for plasma samples and to Schettler and Nussel (1975) for lipids extracted from the liver samples. Cholesterol was determined in plasma and extracted total lipids from liver samples according to Allain et al. (1974). Heparin and sodium citrate were used selectively to precipitate all lipoproteins except the low density lipoprotein (LDL) fractions in plasma which were present in the supernatant (Steinberg, 1981). Also, phosphotungstic acid and magnesium ions were used selectively for precipitating all lipoproteins except the high density lipoprotein (HDL) fractions in plasma which were present in the supernatant (LopesVirella et al., 1977). Then, the LDL- and HDLcholesterol were determined in the supernatant using the same method described for total cholesterol.

\section{Statistical analyses:}

All data were analyzed as a completely randomized design with 10 treatments using the GLM procedure of SAS (SAS Institute, 2004). Adequate contrasts were performed to study the linear and quadratic responses of the different variables to increase levels $(0,2.5,5.0$ and $7.5 \%)$ of each of the three fiber sources. The effects of source and level of fiber inclusion and the interaction were studied. Also, the effects of fiber levels within each fiber source were studied. The experimental unit was the cage for BW and the slaughter chick for all the other traits. Results in tables are presented as leastsquare means. Differences were considered significant at $P<0.05$ and tendencies at $0.10<$ $P<0.05$. Significant differences between means were separated by a least square differences using protected t-test.

\section{RESULTS}

\section{Experimental diets and chicken husbandry:}

Total soluble dietary fiber was higher in SBP $(11.6 \%)$ than those presented in $\mathrm{OH}(0.7 \%)$ and in $\mathrm{PH}(5.1 \%)$ being intermediate (Table 1). As expected, an increase in the level of dietary fiber, each fiber source reduced crude protein and starch content and increased neutral detergent fiber content of the diet (Table 3). Geometric mean diameter values were higher for all treatments diets (by 13.8$20.5 \%$ for $\mathrm{OH}, 26.4-30.1 \%$ for SBP, and 38.4-47.2\% for $\mathrm{PH})$ than for the control diet $(458 \mu \mathrm{m} \pm 1.83 \mathrm{log}$ normal standard deviation).

No mortality was observed during the experimental period for all treatments. Also, dietary fiber sources with different levels of inclusion did not affect live BW or liver relative weight (Table 4).

Plasma lipid metabolites and liver lipid components:

Results in Table (4) indicated that the inclusion of fiber in broiler diets from hatching to $21 \mathrm{~d}$ of age tended to reduce total cholesterol $(P=0.06)$ and to increase HDL cholesterol $(P=0.06)$ in plasma. Moreover, lipid components of the liver including total lipids, triacylglycerides, and total cholesterol were reduced $(P<0.05)$ in response to dietary fiber. 
Table 2. Ingredient composition and calculated analysis of the experimental diets from hatch to $21 \mathrm{~d}$ of age (\%, as-fed basis unless otherwise indicated)

\begin{tabular}{|c|c|c|c|c|c|c|c|c|c|c|}
\hline \multirow[b]{2}{*}{ Item } & \multirow[b]{2}{*}{ Control } & \multicolumn{3}{|c|}{ Oat hulls } & \multicolumn{3}{|c|}{ Sugar beet pulp } & \multicolumn{3}{|c|}{ Pea hulls } \\
\hline & & 2.5 & 5.0 & 7.5 & 2.5 & 5.0 & 7.5 & 2.5 & 5.0 & 7.5 \\
\hline \multicolumn{11}{|l|}{ Ingredient } \\
\hline Rice & 59.75 & 58.25 & 56.75 & 55.27 & 58.25 & 56.75 & 55.27 & 58.25 & 56.75 & 55.27 \\
\hline Soy protein concentrate, $53 \% \mathrm{CP}$ & 24.00 & 23.40 & 22.80 & 22.20 & 23.40 & 22.80 & 22.20 & 23.40 & 22.80 & 22.20 \\
\hline Fish meal, $72 \% \mathrm{CP}$ & 7.60 & 7.41 & 7.22 & 7.03 & 7.41 & 7.22 & 7.03 & 7.41 & 7.22 & 7.03 \\
\hline Soy oil & 5.00 & 4.87 & 4.75 & 4.62 & 4.87 & 4.75 & 4.62 & 4.87 & 4.75 & 4.62 \\
\hline Limestone & 1.15 & 1.12 & 1.09 & 1.06 & 1.12 & 1.09 & 1.06 & 1.12 & 1.09 & 1.06 \\
\hline Fiber source & - & 2.50 & 5.00 & 7.50 & 2.50 & 5.00 & 7.50 & 2.50 & 5.00 & 7.50 \\
\hline Dicalcium phosphate & 1.50 & 1.47 & 1.43 & 1.39 & 1.47 & 1.43 & 1.39 & 1.47 & 1.43 & 1.39 \\
\hline Sodium chloride & 0.30 & 0.29 & 0.29 & 0.28 & 0.29 & 0.29 & 0.28 & 0.29 & 0.29 & 0.28 \\
\hline DL-Methionine, 99\% & 0.20 & 0.20 & 0.19 & 0.19 & 0.20 & 0.19 & 0.19 & 0.20 & 0.19 & 0.19 \\
\hline Vitamin and mineral premix ${ }^{1}$ & 0.50 & 0.49 & 0.48 & 0.46 & 0.49 & 0.48 & 0.46 & 0.49 & 0.48 & 0.46 \\
\hline \multicolumn{11}{|l|}{ Calculated analysis $^{2}$} \\
\hline $\mathrm{AME}_{\mathrm{n}}(\mathrm{kcal} / \mathrm{kg})$ & 3,265 & 3,179 & 3,107 & 3,038 & 3,191 & 3,134 & 3,074 & 3,213 & 3,160 & 3,107 \\
\hline $\mathrm{CP}$ & 22.00 & 21.50 & 21.00 & 20.50 & 21.50 & 21.00 & 20.50 & 21.50 & 21.00 & 20.50 \\
\hline Crude fiber & 1.61 & 2.30 & 2.91 & 3.61 & 2.01 & 2.44 & 2.83 & 2.56 & 3.50 & 4.44 \\
\hline Digestible Lysine & 1.25 & 1.21 & 1.18 & 1.15 & 1.22 & 1.19 & 1.16 & 1.22 & 1.20 & 1.18 \\
\hline Digestible Methionine & 0.58 & 0.56 & 0.55 & 0.53 & 0.56 & 0.55 & 0.53 & 0.56 & 0.55 & 0.53 \\
\hline Digestible Methionine + Cystine & 0.90 & 0.87 & 0.85 & 0.83 & 0.87 & 0.85 & 0.83 & 0.88 & 0.87 & 0.85 \\
\hline Digestible Threonine & 0.81 & 0.78 & 0.77 & 0.75 & 0.79 & 0.77 & 0.75 & 0.79 & 0.77 & 0.76 \\
\hline Calcium & 1.07 & 1.05 & 1.02 & 1.00 & 1.07 & 1.07 & 1.06 & 1.04 & 1.02 & 1.00 \\
\hline Available phosphorus & 0.41 & 0.41 & 0.40 & 0.39 & 0.41 & 0.40 & 0.39 & 0.41 & 0.40 & 0.39 \\
\hline
\end{tabular}

${ }^{\mathrm{T}}$ Provided the following (per kg of diet): vitamin A (transretinyl acetate), 10,000 IU; vitamin D3, (cholecalciferol), 2,000 UI; vitamin E (all-rac-tocopherol acetate), 20 IU;

vitamin $\mathrm{K}$ (bisulphate menadione complex), $3 \mathrm{mg}$; riboflavin, $5 \mathrm{mg}$; pantothenic acid (D-calcium pantothenate), $10 \mathrm{mg}$; nicotinic acid, $30 \mathrm{mg}$; pyridoxine (pyridoxine. $\mathrm{HCl}$ ), $3 \mathrm{mg}$; thiamin (thiamin-mononitrate), $1 \mathrm{mg}$; vitamin $\mathrm{B}_{12}$ (cyanocobalamine), $12 \mu \mathrm{g}$; D-biotin, $0.15 \mathrm{mg}$; choline (choline chloride), $300 \mathrm{mg}$; folic acid, $0.5 \mathrm{mg}$; $\mathrm{Se}$ ( $\mathrm{Na} \mathrm{a}_{2} \mathrm{SeO} \mathrm{O}_{3}$ ), $0.1 \mathrm{mg}$; I (KI), $2.0 \mathrm{mg} ; \mathrm{Cu}\left(\mathrm{CuSO}_{4} \cdot 5 \mathrm{H}_{2} \mathrm{O}\right), 10 \mathrm{mg} ; \mathrm{Fe}\left(\mathrm{FeSO}_{4} \cdot 7 \mathrm{H}_{2} \mathrm{O}\right), 30 \mathrm{mg}$; $\mathrm{Zn}(\mathrm{ZnO}), 100 \mathrm{mg} ; \mathrm{Mn}\left(\mathrm{MnSO}_{4} \cdot \mathrm{H}_{2} \mathrm{O}\right), 100 \mathrm{mg} ;$ and ethoxyquin, $110 \mathrm{mg}$.

${ }^{2}$ According to Fundación Española Desarrollo Nutrición Animal (2008). 
Table 3. Determined chemical composition (\%, as-fed basis) and geometric mean diameter (GMD \pm GSD $\left.^{1}, \mu \mathrm{m}\right)$ of the experimental diets from hatch to $21 \mathrm{~d}$ of age ${ }^{2}$

\begin{tabular}{|c|c|c|c|c|c|c|c|c|c|c|}
\hline \multirow[b]{2}{*}{ Item } & \multirow[b]{2}{*}{ Control } & \multicolumn{3}{|c|}{ Oat hulls } & \multicolumn{3}{|c|}{ Sugar beet pulp } & \multicolumn{3}{|c|}{ Pea hulls } \\
\hline & & 2.5 & 5.0 & 7.5 & 2.5 & 5.0 & 7.5 & 2.5 & 5.0 & 7.5 \\
\hline \multicolumn{11}{|l|}{ Chemical analysis } \\
\hline Gross energy (kcal/kg) & 4,080 & 4,070 & 4,065 & 4,048 & 4,075 & 4,022 & 4,010 & 4,027 & 4,039 & 4,063 \\
\hline Dry matter & 89.9 & 90.0 & 89.8 & 89.7 & 89.9 & 89.9 & 89.9 & 90.3 & 90.2 & 90.0 \\
\hline Crude protein & 22.1 & 21.2 & 21.1 & 20.7 & 21.5 & 21.2 & 20.8 & 21.7 & 21.5 & 21.2 \\
\hline Starch & 43.7 & 42.8 & 41.7 & 40.7 & 42.6 & 41.4 & 40.3 & 42.7 & 41.5 & 40.5 \\
\hline Ether extract & 5.68 & 5.28 & 4.96 & 4.71 & 5.65 & 5.46 & 5.41 & 5.55 & 5.26 & 5.21 \\
\hline Total ash & 7.89 & 7.89 & 7.90 & 7.61 & 8.20 & 8.10 & 7.91 & 8.09 & 8.10 & 7.91 \\
\hline Crude fiber & 1.63 & 2.30 & 2.92 & 3.53 & 2.02 & 2.44 & 2.81 & 2.50 & 3.47 & 4.33 \\
\hline Total dietary fiber & 6.93 & 8.50 & 10.12 & 11.73 & 8.22 & 9.54 & 10.81 & 8.12 & 9.32 & 10.51 \\
\hline Insoluble dietary fiber & 4.77 & 5.89 & 7.61 & 9.33 & 5.29 & 6.41 & 7.53 & 5.89 & 7.01 & 8.13 \\
\hline Soluble dietary fiber & 2.16 & 2.61 & 2.51 & 2.40 & 2.93 & 3.13 & 3.28 & 2.23 & 2.31 & 2.38 \\
\hline Neutral detergent fiber & 4.18 & 5.12 & 7.09 & 9.43 & 4.89 & 5.34 & 6.82 & 4.78 & 5.99 & 7.14 \\
\hline Acid detergent fiber & 1.96 & 2.26 & 2.63 & 3.79 & 1.30 & 1.92 & 2.17 & 2.55 & 3.03 & 3.77 \\
\hline \multicolumn{11}{|l|}{ Physical properties } \\
\hline \multicolumn{11}{|l|}{ Screen size $(\mu \mathrm{m})$} \\
\hline 1,250 & 65.1 & 65.3 & 51.6 & 60.5 & 100.3 & 74.8 & 80.3 & 68.3 & 79.6 & 96.6 \\
\hline 630 & 190.8 & 237.6 & 281.7 & 305.3 & 285.5 & 273.8 & 306.2 & 480.8 & 381.7 & 376.8 \\
\hline 315 & 464.2 & 572.8 & 563.1 & 516.0 & 503.2 & 630.1 & 567.3 & 430.6 & 506.1 & 490.3 \\
\hline 160 & 270.5 & 123.1 & 103.4 & 118.2 & 111.0 & 21.3 & 46.2 & 20.1 & 32.4 & 36.3 \\
\hline 80 & 9.2 & 1.2 & 0.2 & 0.0 & 0.0 & 0.0 & 0.0 & 0.2 & 0.2 & 0.0 \\
\hline$<40$ & 0.2 & 0.0 & 0.0 & 0.0 & 0.0 & 0.0 & 0.0 & 0.0 & 0.0 & 0.0 \\
\hline GMD & 458.0 & 521.0 & 542.0 & 552.0 & 579.0 & 589.0 & 596.0 & 674.0 & 634.0 & 646.0 \\
\hline GSD & 1.83 & 1.67 & 1.62 & 1.65 & 1.77 & 1.63 & 1.64 & 1.57 & 1.62 & 1.65 \\
\hline
\end{tabular}

${ }^{1}$ Log normal standard deviation.

${ }^{2}$ Analyzed in triplicate samples. 
Table 4. Effect of different fiber sources ${ }^{1}$ and levels of inclusion in broiler diets on BW, relative liver weight, plasma lipid metabolites, and liver lipid components at $21 \mathrm{~d}$ of age

\begin{tabular}{|c|c|c|c|c|c|c|c|c|c|c|c|c|}
\hline \multirow[b]{2}{*}{ Item } & \multirow[b]{2}{*}{ BW (g) } & \multirow{2}{*}{$\begin{array}{c}\text { Liver } \\
\text { weight } \\
\text { (g/100 g } \\
\text { BW) }\end{array}$} & \multicolumn{2}{|c|}{ Total lipids } & \multicolumn{2}{|c|}{ Triacylglycerides } & \multicolumn{2}{|c|}{ Total cholesterol } & \multirow[b]{2}{*}{$\begin{array}{l}\text { LDL-cholesterol } \\
\quad(\mathrm{mg} / \mathrm{dL})\end{array}$} & \multirow[b]{2}{*}{$\begin{array}{l}\text { HDL-cholesterol } \\
\quad(\mathrm{mg} / \mathrm{dL})\end{array}$} & \multirow[b]{2}{*}{$\begin{array}{c}\text { HDL:Total } \\
\text { cholesterol ratio }\end{array}$} & \multirow[b]{2}{*}{$\begin{array}{c}\text { HDL:LDL } \\
\text { cholesterol ratio }\end{array}$} \\
\hline & & & $\begin{array}{l}\text { In plasma } \\
(\mathrm{mg} / \mathrm{dL})\end{array}$ & $\begin{array}{l}\text { In liver } \\
(\mathrm{mg} / \mathrm{g})\end{array}$ & $\begin{array}{l}\text { In plasma } \\
(\mathrm{mg} / \mathrm{dL})\end{array}$ & $\begin{array}{l}\text { In liver } \\
(\mathrm{mg} / \mathrm{g})\end{array}$ & $\begin{array}{l}\text { In plasma } \\
(\mathrm{mg} / \mathrm{dL})\end{array}$ & $\begin{array}{l}\text { In liver } \\
(\mathrm{mg} / \mathrm{g})\end{array}$ & & & & \\
\hline \multicolumn{13}{|l|}{ Treatment } \\
\hline Control & 967 & 3.015 & 233.9 & $35.7^{\mathrm{a}}$ & $18.61^{\mathrm{a}}$ & $7.37^{\mathrm{a}}$ & $161.4^{\mathrm{a}}$ & $2.66^{\mathrm{a}}$ & 70.3 & $44.9^{c}$ & $0.28^{\mathrm{c}}$ & 0.69 \\
\hline $2.5 \% \mathrm{OH}$ & 942 & 2.963 & 226.5 & $32.7^{\mathrm{ab}}$ & $17.65^{\mathrm{ab}}$ & $6.60^{\mathrm{ab}}$ & $156.9^{\mathrm{ab}}$ & $2.28^{\mathrm{abc}}$ & 68.8 & $59.6^{\mathrm{ab}}$ & $0.38^{\mathrm{ab}}$ & 0.90 \\
\hline $5.0 \% \mathrm{OH}$ & 934 & 2.953 & 223.7 & $30.4^{\mathrm{ab}}$ & $17.52^{\mathrm{ab}}$ & $6.28^{\mathrm{ab}}$ & $150.7^{\mathrm{ab}}$ & $2.11^{\mathrm{bc}}$ & 66.3 & $61.0^{\mathrm{a}}$ & $0.41^{\mathrm{a}}$ & 0.97 \\
\hline $7.5 \% \mathrm{OH}$ & 922 & 2.923 & 222.9 & $29.6^{\mathrm{b}}$ & $17.38^{\mathrm{ab}}$ & $5.90^{\mathrm{b}}$ & $149.1^{\mathrm{ab}}$ & $2.05^{\mathrm{bc}}$ & 64.6 & $61.2^{\mathrm{a}}$ & $0.41^{\mathrm{a}}$ & 0.98 \\
\hline $2.5 \%$ SBP & 931 & 2.983 & 222.6 & $31.8^{\mathrm{ab}}$ & $17.75^{\mathrm{ab}}$ & $7.06^{\mathrm{ab}}$ & $154.0^{\mathrm{ab}}$ & $2.47^{\mathrm{b}}$ & 68.0 & $48.5^{\mathrm{bc}}$ & $0.32^{\mathrm{bc}}$ & 0.75 \\
\hline $5.0 \%$ SBP & 924 & 2.972 & 220.1 & $30.3^{\mathrm{b}}$ & $17.35^{\mathrm{ab}}$ & $6.38^{\mathrm{ab}}$ & $152.4^{\mathrm{ab}}$ & $2.39^{\mathrm{abc}}$ & 65.3 & $53.5^{\mathrm{abc}}$ & $0.36^{\mathrm{abc}}$ & 0.93 \\
\hline $7.5 \%$ SBP & 920 & 2.962 & 218.1 & $29.6^{\mathrm{b}}$ & $16.56^{\mathrm{b}}$ & $6.01^{\mathrm{b}}$ & $151.9^{\mathrm{ab}}$ & $2.33^{\mathrm{abc}}$ & 64.5 & $54.7^{\mathrm{abc}}$ & $0.36^{\mathrm{abc}}$ & 0.89 \\
\hline $2.5 \% \mathrm{PH}$ & 932 & 2.978 & 231.4 & $33.1^{\mathrm{ab}}$ & $18.36^{\mathrm{ab}}$ & $6.79^{\mathrm{ab}}$ & $152.3^{\mathrm{ab}}$ & $2.31^{\mathrm{abc}}$ & 68.6 & $45.5^{\mathrm{c}}$ & $0.30^{\mathrm{bc}}$ & 0.71 \\
\hline $5.0 \% \mathrm{PH}$ & 922 & 2.968 & 229.7 & $31.3^{\mathrm{ab}}$ & $17.93^{\mathrm{ab}}$ & $6.43^{\mathrm{ab}}$ & $144.4^{\mathrm{b}}$ & $2.14^{\mathrm{bc}}$ & 64.9 & $46.6^{c}$ & $0.33^{\mathrm{abc}}$ & 0.74 \\
\hline $7.5 \% \mathrm{PH}$ & 917 & 2.952 & 216.3 & $30.7^{\mathrm{ab}}$ & $17.52^{\mathrm{ab}}$ & $6.10^{\mathrm{b}}$ & $142.6^{\mathrm{b}}$ & $1.95^{\mathrm{c}}$ & 63.8 & $51.8^{\mathrm{abc}}$ & $0.37^{\mathrm{abc}}$ & 0.85 \\
\hline $\operatorname{SEM}(n=6)^{2}$ & 25.4 & 0.1225 & 9.84 & 1.92 & 0.710 & 0.436 & 5.48 & 0.182 & 6.15 & 4.27 & 0.031 & 0.120 \\
\hline \multicolumn{13}{|l|}{ Fiber source } \\
\hline $\mathrm{OH}$ & 932 & 2.947 & 224.3 & 30.9 & 17.63 & 6.26 & 152.2 & 2.15 & 66.6 & $60.6^{\mathrm{a}}$ & $0.40^{\mathrm{a}}$ & 0.95 \\
\hline SBP & 925 & 2.972 & 220.3 & 30.5 & 17.22 & 6.49 & 152.8 & 2.39 & 65.9 & $52.2^{\mathrm{ab}}$ & $0.34^{\mathrm{ab}}$ & 0.85 \\
\hline $\mathrm{PH}$ & 924 & 2.966 & 225.8 & 31.7 & 17.94 & 6.44 & 146.5 & 2.13 & 65.8 & $48.0^{\mathrm{b}}$ & $0.33^{\mathrm{b}}$ & 0.76 \\
\hline \multicolumn{13}{|l|}{ Fiber level (\%) } \\
\hline 0.0 & 967 & 3.015 & 233.9 & $35.7^{\mathrm{x}}$ & $18.61^{\mathrm{x}}$ & $7.37^{\mathrm{x}}$ & $161.4^{\mathrm{x}}$ & $2.66^{\mathrm{x}}$ & 70.3 & $44.9^{y}$ & $0.28^{y}$ & 0.69 \\
\hline 2.5 & 935 & 2.975 & 226.8 & $32.5^{x y}$ & $17.92^{\mathrm{xy}}$ & $6.82^{x y}$ & $154.4^{\mathrm{xy}}$ & $2.35^{\mathrm{xy}}$ & 68.5 & $51.2^{x y}$ & $0.33^{y}$ & 0.78 \\
\hline 5.0 & 927 & 2.964 & 224.5 & $30.6^{y}$ & $17.60^{x y}$ & $6.36^{\mathrm{xy}}$ & $149.2^{y}$ & $2.21^{\mathrm{y}}$ & 65.5 & $53.7^{x y}$ & $0.36^{\mathrm{xy}}$ & 0.89 \\
\hline 7.5 & 920 & 2.946 & 219.1 & $29.9^{y}$ & $17.16^{\mathrm{y}}$ & $6.00^{y}$ & $147.9^{\mathrm{y}}$ & $2.11^{\mathrm{y}}$ & 64.3 & $55.9^{x}$ & $0.38^{\mathrm{x}}$ & 0.90 \\
\hline $\begin{array}{l}\text { General model } \\
\text { Contrasts }\end{array}$ & 0.9706 & 1.0000 & 0.9553 & 0.4589 & 0.7588 & 0.3440 & 0.4497 & 0.2376 & 0.9985 & 0.0387 & 0.0591 & 0.5783 \\
\hline Control vs. all & 0.1649 & 0.6977 & 0.3187 & 0.0243 & 0.1668 & 0.0397 & 0.0641 & 0.0279 & 0.5219 & 0.0604 & 0.0248 & 0.1865 \\
\hline Fiber source & 0.9105 & 0.9687 & 0.7793 & 0.7598 & 0.4667 & 0.7979 & 0.3026 & 0.1512 & 0.9860 & 0.0025 & 0.0195 & 0.1756 \\
\hline Fiber level & 0.7769 & 0.9610 & 0.6186 & 0.2428 & 0.4186 & 0.0844 & 0.3093 & 0.2709 & 0.6941 & 0.4120 & 0.1836 & 0.4419 \\
\hline Linear & & & & & & & & & & & & \\
\hline Fiber level & 0.1207 & 0.6369 & 0.1878 & 0.0068 & 0.0695 & 0.0052 & 0.0226 & 0.0081 & 0.3439 & 0.0243 & 0.0056 & 0.0862 \\
\hline OH level & 0.2354 & 0.6248 & 0.4193 & 0.0192 & 0.2344 & 0.0193 & 0.0833 & 0.0184 & 0.4807 & 0.0115 & 0.0042 & 0.0822 \\
\hline SBP level & 0.2197 & 0.7681 & 0.2622 & 0.0237 & 0.0445 & 0.0189 & 0.2257 & 0.1890 & 0.4699 & 0.0797 & 0.0568 & 0.1524 \\
\hline PH level & 0.1911 & 0.7313 & 0.2208 & 0.0528 & 0.2501 & 0.0383 & 0.0115 & 0.0069 & 0.4037 & 0.2620 & 0.0553 & 0.3456 \\
\hline
\end{tabular}

${ }^{\mathrm{T}} \mathrm{OH}=$ Oat hulls, SBP $=$ Sugar beet pulp and $\mathrm{PH}=$ Pea hulls

${ }^{2}$ Standard error of the mean ( $n=$ number of observations).

${ }^{\mathrm{a}-\mathrm{c}}$ Means for treatment or fiber source within the same column with different superscripts differ significantly $(P<0.05)$.

${ }^{\mathrm{x}-\mathrm{y}}$ Means for fiber level effect within the same column with different superscripts had linear effect at $P<0.05$. 
Type of fiber did not affect total lipids, triacylglycerides, or LDL cholesterol in the plasma or the relative weight $(\% \mathrm{BW})$ of the liver. Plasma $\mathrm{HDL}$, however, was higher in birds fed $\mathrm{OH}$ than in birds fed $\mathrm{PH}$ or the control diet with birds fed SBP being intermediate $(P<0.01)$. An increase in the level of fiber in the diet from 0 to $7.5 \%$ tended to decrease triglycerides in the liver from 7.37 to 6.00 $\mathrm{mg} / \mathrm{g}$ across treatments $(P=0.08)$ but did not affect any of the other traits studied. Linear reduction was observed for liver lipids components in response to dietary fiber levels $(P<0.01)$. The same trend was observed for total cholesterol in plasma $(P<0.05)$. In addition, plasma HDL-cholesterol was linearly increased by dietary fiber levels $(P<0.05)$. However, no quadratic effects were observed for all traits.

HDL-cholesterol was increased in chickens fed $2.5 \% \mathrm{OH}$ or more but not by dietary, neither SBP nor PH (Figure 1). Liver lipids components were reduced in chickens fed diets containing 7.5\% $\mathrm{OH}$ comparing with those fed the control diet with chickens fed diets containing either 2.5 or $5 \% \mathrm{OH}$ being intermediate (Figure 1). The same trend was observed by dietary $\mathrm{PH}$ for liver triglycerides and total cholesterol. Also, dietary $5 \%$ or more SBP reduced liver total lipids and triglycerides comparing with non-dietary SBP with dietary $2.5 \%$ SBP being intermediate.

\section{DISCUSSION}

\section{Experimental diets and chicken husbandry:}

Results of the current trial indicated that dietary fiber sources differing in solubility and physicochemical properties did not affect live BW and liver relative weight $(\% \mathrm{BW})$. These results are consistent with data of Jiménez-Moreno et al. (2011) for $\mathrm{PH}$ and with the results obtained by JiménezMoreno et al. (2013) for OH or SBP for broilers from 1 to $18 \mathrm{~d}$ of age fed the same levels of fiber inclusion studied in the current trial. In the same context, Jiménez-Moreno et al. (2009 \& 2010) reported that 2.5 and $5.0 \% \mathrm{OH}$, rice hulls or sunflower hulls could be included in low fiber diets for broilers from 1 to $21 \mathrm{~d}$ of age without impairing broiler performance. Pettersson and Razdan (1993) observed that broilers fed a diet that contained 2.3\% SBP had higher BW and better feed conversion ratio from 1 to $21 \mathrm{~d}$ of age than broilers fed the control diet. However, when the level of SBP was increased to 4.6 and $9.2 \%$ in broiler diets growth performance was impaired. An excess of fiber could cause a significant distension of the GIT with a concomitant increase in maintenance requirements of the birds, as demonstrated by Hansen et al. (1992) in rats and Jørgensen et al. (1996) in pigs. This discrepancy in the results might be explained by the high pectin content of the SBP that increased water holding or to the differences in the physicochemical characteristics of the fiber sources used which might affect gut motility, microbiota growth and voluntary FI of the birds. Thus, bulk and weight of the fresh excreta might be increased as reported by Jørgensen et al. (1996) who observed an increase in moisture content of the excreta as the level of pea fiber (an ingredient with a high pectin content) increased but not when oat bran was used. Jiménez-Moreno et al. (2011) reported that the inclusion of $\mathrm{PH}$ in the diet improved energy efficiency in broilers from 1 to $18 \mathrm{~d}$ of age which is in agreement with results of González-Alvarado et al. (2010) in broilers from 1 to $42 \mathrm{~d}$ of age fed diets containing $3.0 \% \mathrm{OH}$ or SBP and suggests that the beneficial effects of dietary fiber on growth performance of broilers were due primarily to an increase in diet digestibility which resulted in more nutrients available for growth.

\section{Plasma lipid metabolites and liver lipid components:}

Dietary fiber reduced plasma total cholesterol and liver lipid components and increased plasma HDL cholesterol in broilers at $21 \mathrm{~d}$ of age, supporting the hypothesis of hypolipidaemic effects of dietary fiber that was suggested by Trowell (1972) and proofed by several publications in poultry, animals, and humans (Anderson et al. 1991b; Anderson et al. 1994; Razdan et al., 1997; Viveros et al., 2007; Zhang et al., 2009 and Crowe1 et al., 2012). However, dietary fiber sources differ in solubility and physicochemical properties did not affect the most of lipid metabolism in either plasma or liver. It has been reported that dietary soluble fibers reduced serum and liver cholesterol however, insoluble fibers had little effects on these traits (Anderson et al., 1994 and Slavin, 2013). On the other hand, Sarikhan et al. (2009) found that broilers fed diets supplemented with insoluble fibers up to $0.75 \%$ from 1 to $42 \mathrm{~d}$ of age did not affect serum lipids metabolites at $21 \mathrm{~d}$ of age. However, they observed that triglycerides, total cholesterol, and LDL-cholesterol were reduced and HDL-cholesterol was increased in response to dietary insoluble fibers up to $0.75 \%$ at $42 \mathrm{~d}$ of age. In the same respect, Kahlon et al. (1993) reported that dietary oat fiber or its fractions lowered elevated plasma cholesterol, LDL-cholesterol, and triglycerides in Hamsters. The same trend was observed in men by Anderson et al. (1984 and 1991a). The discrepancy among the authors is not known. However, it might be explained, at least in part, by the differences in species, age and duration of fiber inclusion in the diet as factors affecting broilers responding to dietary lower-cholesterol agents. Meluzzi et al. (1992) reported that age, sex, strain and sampling season varying blood constituents in broilers. In addition, Chau and Cheung (1999) suggesting that the cholesterollowering effects of the insoluble dietary fibers might be caused by the indirect influences on lowering the intestinal absorption of cholesterol by the variation among fibers in physicochemical properties. 

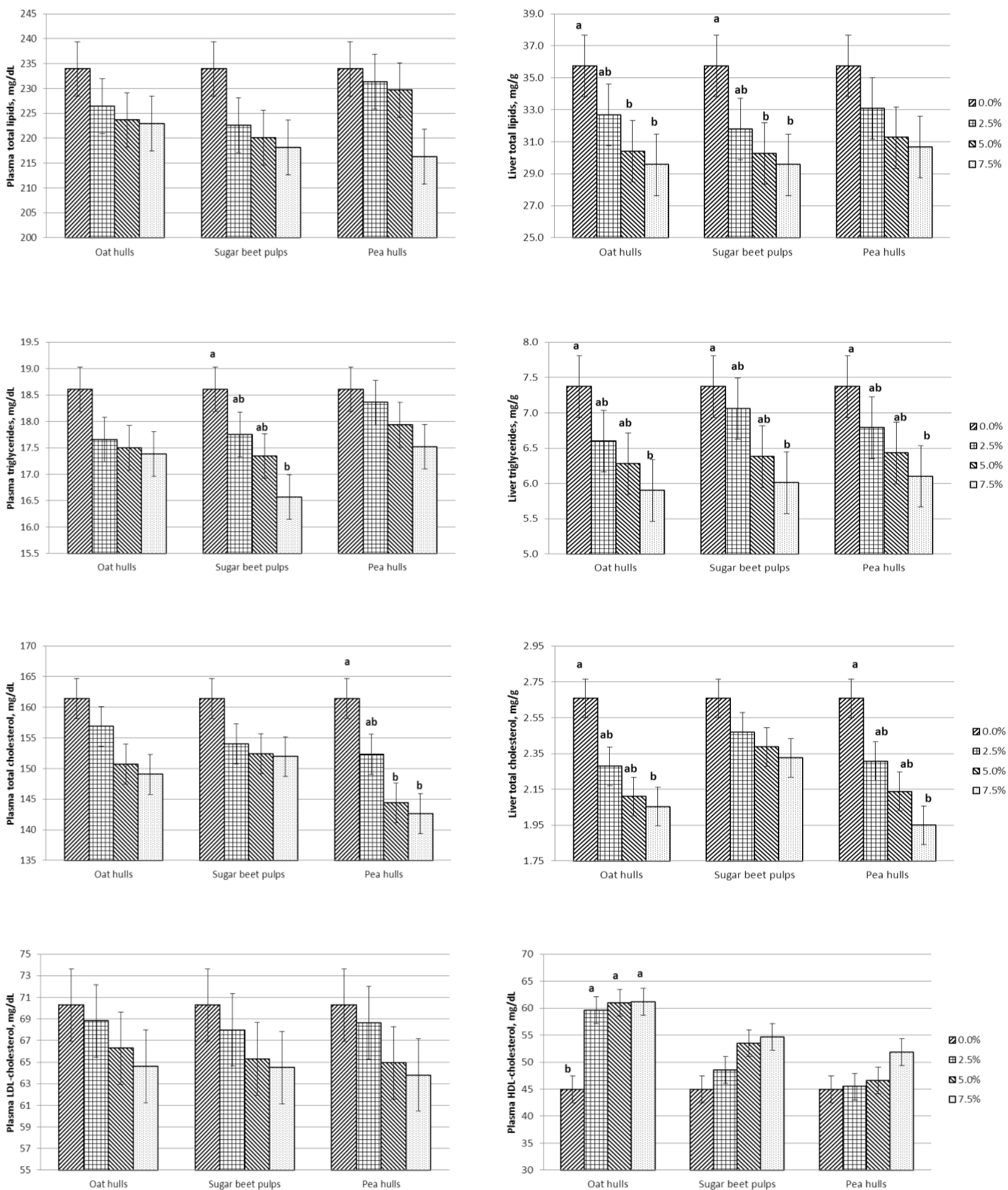

Figure 1. Effect of different levels inclusion of each fiber source in broiler diets on lipid metabolism traits in plasma and liver at $\mathbf{2 1} \mathbf{d}$ of age. Columns within each fiber source with different superscripts differ significantly $(P<0.05)$ 
In the current trial, plasma total cholesterol and liver components were linearly reduced and plasma HDL-cholesterol was linearly increased $(P<0.05)$ in response to dietary fiber levels up to $7.5 \%$. The hypocholesterolemic effects of dietary fibers with different levels may be attributed to one or more of the following mechanisms: 1] the modification of bile acid absorption and metabolism by binding them with cholesterol (Hargis, 1988; Topping, 1991; Esmail, 2012), 2] the interference with lipid absorption and metabolism (Hargis, 1988; Topping, 1991; Wang et al., 1992; Hashish and Abd El-Samee, 2012), 3] the production of short-chain fatty acids from fermentation of fiber in the colon that interfere with cholesterol synthesis (Gallaher et al., 1993; Anderson et al. 1994; Lopez et al., 1999 and Hashish and Abd El-Samee, 2012 and Slavin, 2013), 4] the inhibition of cholesterol biosynthesis due to suppressing the enzymatic activity of HMG-CoA reductase by the bioactive anti-nutritive factors present in fibers (Burger et al., 1984; Qureshi et al., 1991; Esmail, 2012 and Hashish and Abd El-Samee, 2012), 5] the alterations in the concentrations of or sensitivity to insulin or other hormones (Anderson et al. 1994 and Hashish and Abd El-Samee, 2012), 6] the shortening of intestinal transit time to increase fecal sterol excretion (Hargis, 1988; Slavin and Feirtag, 2011 and Hashish and Abd El-Samee, 2012).

It is concluded that the inclusion of fiber in the diet modified in different ways lipid metabolism in broilers at $21 \mathrm{~d}$ of age but that fiber sources differing widely in solubility and physicochemical properties had little impact on these traits. However, the hypolipidaemic effects of fiber was accumulated in the liver as noted by the reduction in lipid components in the liver at this age. In general, dietary fibers might play an important role in lipid metabolism as hypolipidaemic agent in broiler chickens.

\section{REFERENCES}

Allain, C.C., L.S. Poon, C.S.G. Chan, W. Richmond, and P.C. Fu., 1974. Enzymatic determination of total serum cholesterol. Clin. Chem., 20: 470 475.

American Society of Agriculture Engineers, 1995. Method of determining and expressing fineness of feed materials by sieving, in: Agriculture Engineers Yearbook of Standards, ASAE standard S319.2. St. Joseph, MO, pp. 461-462.

Anderson, J.W., L. Story, B. Sieling, W.J.L. Chen, M.S. Petro, and J. Story, 1984. Hypocholesterolemic effects of oat-bran or bean intake for hypercholesterolemic men. Am. J. Clin. Nutr., 40: 1146-1155.

Anderson, J.W., and A.E. Siesei. 1990a, Hypocholesterolemic effects of oat products. In: New Developments in Dietary Fiber (Furda, I., and C. J. Brine, eds.), pp. 17-36. Plenum Press, New York, NY.

Anderson, J.W., D.A. Deakins, T.L. Floore, B.M. Smith, and S.E. Whitis, 1990b. Dietary fiber and coronary heart disease. Crit. Rev. Food Sci. Nutr., 29: 95-147.

Anderson, J.W., T.L. Floore, P.B. Geil, D.S. O'Neal, and T. Balm, 1991a. Hypocholesterolemic effects of different bulk-forming hydrophilic fibers as adjuncts to dietary therapy in mild to moderate hypercholesterolemia. Arch. Intern. Med., 151: 1597-1602.

Anderson, J.W., N.H. Gilinsky, D.A. Deakins, S.F. Smith, D.S. O'Neal, D.W. Dillon, and P.R. Oeltgen, 1991b. Lipid responses of hypercholesterolemic men to oat bran and wheat bran intake. Am. J. Clin. Nutr. 54: 678-683.

Anderson, J.W., A.E. Jones, and S. Riddell-Mason, 1994. Ten different dietary fibers have significantly different effects on serum and liver lipids of cholesterol-fed rats. J. Nutr. 124: 78-83.

Brownawell, A.M., W. Caers, G.R. Gibson, C.W.C. Kendall, K.D. Lewis, Y. Ringel, and J.L. Slavin, 2012. Prebiotics and the health benefits of fiber: Current regulatory status, future research, and goals. J. Nutr., 142: 1-13.

AOAC International, 2000. Official Methods of Analysis, seventeenth ed. Association of Official Analytical Chemists, Gaithersburg, MD.

Bligh, E.G., and W.J. Dyer., 1959. A rapid method of total lipid extraction and purification. Can. J. Biochem. Physiol., 37: 911-917.

Boletín Oficial del Estado, 1995. Real Decreto 2257/1994 por el que se aprueba los métodos oficiales de análisis de piensos o alimentos para animales y sus primeras materias. BOE 52: 71617237.

Boletín Oficial del Estado, 2007. Ley 32/2007 para el cuidado de los animales, en su explotación, transporte, experimentación y sacrificio. BOE 268: 45914-45920.

Burger, W.C., A. A. Qureshi, Z.Z. Din, N. Abuirmeileh, and C.E. Elson, 1984. Suppression of cholesterol biosynthesis by constituents of barleykernels. Atherosclerosis, 51: 75-87.

Chau, C., and P. Cheung, 1999. Effects of the physico-chemical properties of three legume fibers on cholesterol absorption in hamsters. Nutr. Res., 19(2): 257-265.

Crowe1, F.L., T.J. Key, P.N. Appleby, K. Overvad, E.B. Schmidt, R. Egeberg, A. Tjønneland, R. Kaaks, B. Teucher, H. Boeing, C. Weikert, A. Trichopoulou, V. Ouranos, E. Valanou, G. Masala, S. Sieri, S. Panico, R. Tumino, G. Matullo, H.B. Bueno-de-Mesquita, J.M.A. Boer, J.W.J. Beulens, Y.T. van der Schouw, J.R. Quiro's, G. Buckland, M.J. Sanchez, M. Dorronsoro, J.M. Huerta, C. Moreno-Iribas, B. Hedblad, J.H. Jansson, P. Wennberg, K.T. Khaw, N. Wareham, P. Ferrari, A.K. Illner, S.C. Chuang, 
T. Norat, J. Danesh., and E. Riboli, 2012. Dietary fibre intake and ischaemic heart disease mortality: the European Prospective Investigation into Cancer and Nutrition-Heart study. European J. Clin. Nutr., 66: 950-956.

Delzenne, N.M., C. Daubioul, A. Neyrinck, M. Lasa, and H.S. Taper, 2002. Inulin and oligofructose modulate lipid metabolism in animals: review of biochemical events and future prospects. Br. J. Nutr., 87(2): S255-S259.

Dubois, C., L. Cara, M. Armand, P. Borel, M. Senft, H. Portugal, A. Pauli, P. Bernard, H. Lafont, and D. Lairon, 1993. Effects of pea and soybean fiber on postprandial lipemia and lipoproteins in healthy-adults. Eur. J. Clin. Nutr., 47(7): 508520.

Esmail, S.H. 2012. Fiber plays a supporting role in poultry nutrition. WorldPoultry, 28(2): 21-26.

Fossati, P., and L. Prencipe, 1982. Serum triglycerides determined colorimetrically with an enzyme that produces hydrogen peroxide. Clin. Chem., 28: 2077-2080.

Fundación Española Desarrollo Nutrición Animal, 2008. Necesidades nutricionales para avicultura: Pollos de carne y aves de puesta. Lázaro, R., G. G. Mateos (Eds.), Fundación Española Desarrollo Nutrición Animal, Madrid, Spain.

Frikha, M., D.G. Valencia, A. de Coca-Sinova, R. Lázaro, and G.G. Mateos, 2013. Ileal digestibility of amino acids of unheated and autoclaved pea protein concentrate in broilers. Poult. Sci., 92: 1848-1857.

Gallaher, D.D., C.A. Hassel, K.J. Lee, and C.M. Gallaher, 1993. Viscosity and fermentability as attributes of dietary fiber responsible for the hypocholesterolemic effect in hamsters. J. Nutr., 123: 240-252.

González-Alvarado, J.M., E. Jiménez-Moreno, D. González-Sánchez, R. Lázaro, and G.G. Mateos, 2010. Effect of inclusion of oat hulls and sugar beet pulp in the diet on productive performance and digestive traits of broilers from 1 to 42 days of age. Anim. Feed Sci. Technol., 162: 37-46.

Hansen, I., K.E. Bach Knudsen, and B.O. Eggum, 1992. Gastrointestinal implications in the rat of wheat bran, oat bran and pea fibre. Br. J. Nutr., 68: 451-462.

Hargis, P.S., 1988. Modifying egg yolk cholesterol in the domestic fowl-a review. World's Poult. Sci. J., 44: 15-29.

Hashish, S.M., and L.D. Abd El-Samee, 2012. Egg yolk cholesterol of hens fed barley malt rootlets. Iranian J. of Applied Anim. Sci., 2(1): 83-88.

Jiménez-Moreno, E., J.M. González-Alvarado, A. González-Serrano, R. Lázaro, and G.G. Mateos, 2009. Effect of dietary fiber and fat on performance and digestive traits of broilers from one to twenty-one days of age. Poult. Sci., 88: 2562-2574.

Jiménez-Moreno, E., J.M. González-Alvarado, D. González-Sánchez, R. Lázaro, and G.G. Mateos.
2010. Effects of type and particle size of dietary fiber on growth performance and digestive traits of broilers from one to twenty-one day of age. Poult. Sci., 89: 2197-2212.

Jiménez-Moreno, E., S. Chamorro, M. Frikha, H.M. Safaa, R. Lázaro, and G.G. Mateos, 2011. Effects of increasing levels of pea hulls in the diet on productive performance and digestive traits of broilers from one to eighteen days of age. Anim. Feed Sci. Technol., 168: 100-112.

Jiménez-Moreno, E., M. Frikha, A. de Coca-Sinova, J. García, and G.G. Mateos, 2013. Oat hulls and sugar beet pulp in diets for broilers. 1. Effects on growth performance and nutrient digestibility. Anim. Feed Sci. Technol., 182: 33-43.

Jørgensen, H., X. Zhao, K.E.B. Knudsen, and B.O. Eggum, 1996. The influence of dietary fiber source and level on the development of the gastrointestinal tract, digestibility and energy metabolism in broiler chickens. Br. J. Nutr., 75: 379-395.

Kahlon, T.S., F.I. Chow, B.E. Knuckles, and M.M. Chiu, 1993. Cholesterol-lowering effects in Hamsters of $\beta$-glucan-enriched barley fraction, dehulled whole barley, rice bran, and oat bran and their combinations. Cereal Chem., 70(4): 435440.

Knight, J.A., S.J. Anderson, and J.M. Rawle, 1972. Chemical bases of the sulfo-phospho-vanillin reaction for estimating total serum lipids. Clin. Chem., 18: 199-202.

Lairon, D., 1996. Dietary fibres: Effects on lipid metabolism and mechanisms of action. Eur. J. Clin. Nutr., 50: 125-133.

Lopes-Virella, M.F., P. Stone, S. Ellis, and J.A. Collwell, 1977. Cholesterol determination in high-density lipoproteins separated by three different methods. Clin. Chem., 23: 882-884.

Lopez, H.W., M.A. Levrat, C. Guy, A. Messanger, C. Demigne, and C. Remesy, 1999. Effects of soluble corn bran arabinoxylans on cecal digestion, lipid metabolism, and mineral balance (Ca, Mg) in rats. J. Nutr. Biochemistry, 10: 500509.

Mohiti-Asli, M., M. Shivazad, M. Zaghari, M. Rezaian, S. Aminzadeh, and G.G. Mateos, 2012a. Effects of feeding regimen, fiber inclusion, and crude protein content of the diet on performance and egg quality and hatchability of eggs of broiler breeder hens. Poult. Sci., 91: 3097-3106.

Mohiti-Asli, M., M. Shivazad, M. Zaghari, S. Aminzadeh, M. Rezaian, and G.G. Mateos, 2012b. Dietary fibers and crude protein content alleviate hepatic fat deposition and obesity in broiler breeder hens. Poult. Sci., 91: 3107-3114.

Meluzzi, A., G. Primiceri, R., Giordani, and G. Fabris, 1992. Determination of blood constituents reference values in broilers. Poult. Sci., 71: 337345.

Pettersson, D., and P. Aman, 1991. Effects of increasing levels of sugar-beet pulp in broiler 
chicken diets on nutrient digestion and serum lipids. J. of the Sci. of Food and Agric., 57(2): 273-286.

Pettersson, D., and A. Razdan, 1993. Effects of increasing levels of sugar-beet pulp in broiler chicken diets on nutrient digestion and serum lipids. Br. J. Nutr., 70: 127-137.

Qureshi, A.A., V. Chaudhary, F.E. Weber, E. Chicoye, and N. Qureshi, 1991. Effects of brewer's grain and other cereals on lipid metabolism in chickens. Nutr. Research, 11: 159162.

Razdan, A., and D. Pettersson, 1994. Effects of feeding restriction and meal pattern of a sugar beet-containing diet and control diet on nutrient digestibility, plasma lipid concentrations and postprandial triacylglycerol response in broiler chickens. Br. J. Nutr., 71: 389-400.

Razdan, A., D. Pettersson, and J. Pettersson, 1997. Broiler chicken body weights, feed intakes, plasma lipid and small-intestinal bile acid concentrations in response to feeding of chitosan and pectin. Br. J. Nutr., 78: 283-291.

Sarikhan, M., H.A. Shahryari, K. Nazer-Adl, B. Gholizadeh, and B. Behesht, 2009. Effects of insoluble fiber on serum biochemical characteristics in broiler. Int. J. Agric. Biol., 11: 73-76.

Sarmento, R.F.B., and R.C. Ticiana, 2013. Dietary fiber - Adequate intake and effects on metabolism health. Arquivos Brasileiros De Endocrinologia E Metabologia, 57(6): 397-405.

SAS Inst., 2004. SAS/STATs User's Guide, Version 9.1. SAS Inst. Inc., Cary, NC.

Schettler, G., and E. Nussel, 1975. Method for triglycerides. Aeb. Med. Soz. Med. Prav. Med., 10: 25-29.

Slavin, J.L, 2008. Position of the American Dietetic Association: Health implications of dietary fiber. J. Am. Diet. Assoc., 108: 1716-1731.

Slavin, J.L., 2013. Fiber and Prebiotics: Mechanisms and Health Benefits. Nutrients, 5: 1417-1435.

Slavin, J.L., and J. Feirtag, 2011. Chicory inulin does not increase stool weight or speed up intestinal transit time in healthy male subjects. Food Function, 2: 72-77.

Steinberg, D., 1981. Metabolism of lipoproteins at the cellular level in relation to atherogenesis. Metab. Aspect. Cardiovasc. Dis., 1: 31-48.
Topping, D.L., 1991. Soluble fibers: effect on plasma cholesterol and colonic fermentation. Nutr. Review, 49: 195-203.

Trowell, H., 1972. Ischemic heart disease and dietary fiber. Am. J. Clin. Nutr., 25: 926-932.

Uberoi, S.K., S. Vadhera, and G.L. Soni, 1992. Role of dietary fiber from pulses and cereals as hypocholesterolemic and hypolidemic agent. J. Food Sci. Technol., 29: 281-283.

Van Soest, P.J., J.B. Robertson, and A. Lewis, 1991. Methods for dietary fiber, neutral detergent fiber, and non-starch polysaccharides in relation to animal nutrition. J. Dairy Sci., 74: 3583-3597.

Velasco, S., L.T. Ortiz, C. Alzueta, A. Rebolé, J. Trevio, and M.L. Rodriguez, 2010. Effect of inulin suplementation and dietary fat source on performance, blood serum metabolites, liver lipids, abdominal fat deposition, and tissue fatty acid composition in broiler chickens. Poult. Sci., 89: $1651-1662$.

Viveros, A., C. Centeno, I. Arija, and A. Brenes, 2007. Cholesterol-lowering effects of dietary lupin (Lupinus albus var multolupa) in chicken diets. Poult. Sci., 86: 2631-2638.

Wang, L., R.K. Newman, C.W. Newman, and P.J. Hofer, 1992. Barley $\beta$-glucans alter intestinal viscosity and reduce plasma cholesterol concentrations in chicks. J. Nutr., 122: 22922297.

Wang, L., R.B. Stephen, K. Rosemary, R.D. Newman, and C. Walter, 1997. Comparative cholesterol lowering effects of barley $\beta$-glucan and barley oil in golden Syrian hamsters. Nutr. Research, 17: 77-88.

Yusrizal, and T.C. Chen, 2003. Effect of adding chicory fructans in feed on broiler growth performance, serum cholesterol and intestinal length. Intern. J. Poult. Sci., 2(3): 214-219.

Zhang, G.F., Z.B. Yang, Y. Wang, W.R. Yang, S.Z. Jiang, and G.S. Gai, 2009. Effects of ginger root (Zingiber officinale) processed to different particle sizes on growth performance, antioxidant status, and serum metabolites of broiler chickens. Poult. Sci., 88: 2159-2166.

Zhang, G.G., Z.B. Yang, Y. Wang, and W.R. Yang, 2013. Effects of Astragalus membranaceus root processed to different particle sizes on growth performance, antioxidant status, and serum metabolites of broiler chickens. Poult. Sci., 92: 178-183. 
مكونات التمثيل الغذائي للاهون في بلازما وكبد كتاكيت التسمين علي عمر 21 يوم كإستجابة للتفذية علي مصادر مختلفة من الألياف التفيل

حسام محمد صفاء²،، إينكارنا خيمنيث مورينو2، محمد الفريخة²، جونزالو جونزالز ماتيوس22 1- قسم الإنتاج الحيو اني-كلية الزراعة_جامعة القاهرة-الجيزة 12613-ج.م.ع.، 2- قسم الإنتاج الحيو اني-جامعة البوليتقنية بدريد-مدريد 28040اسبانيا

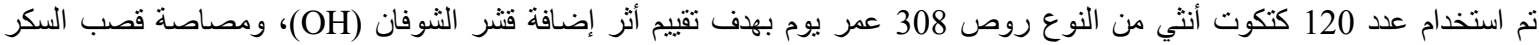

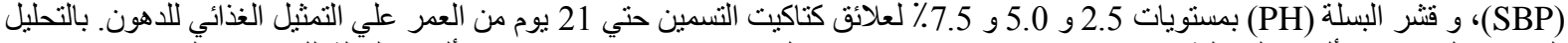

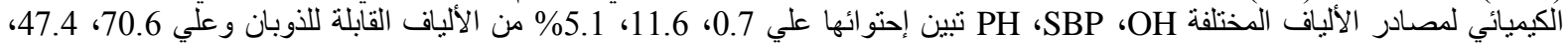

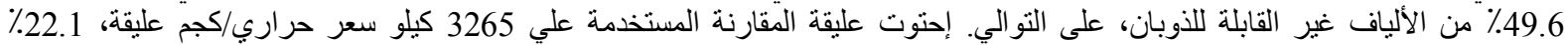

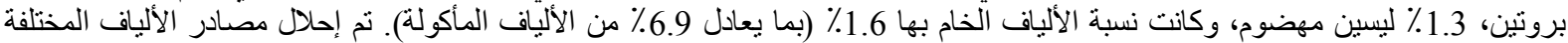

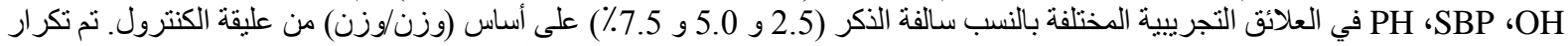

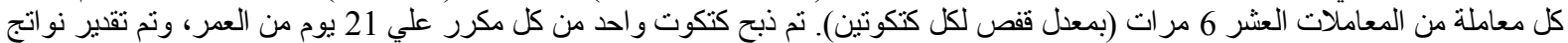

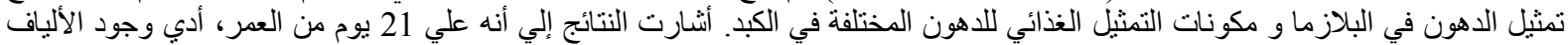

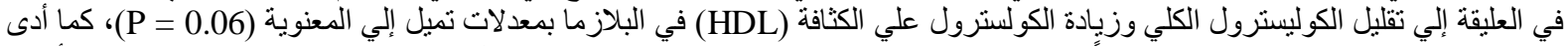

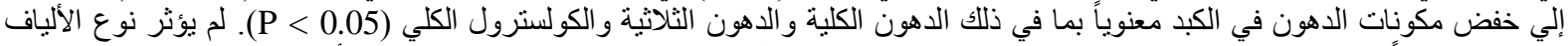

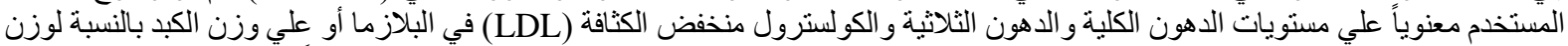

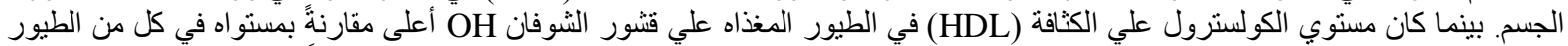

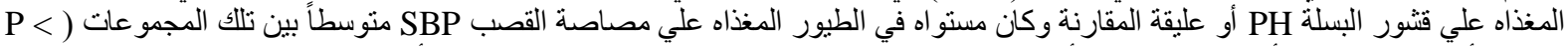

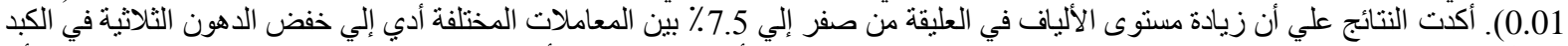

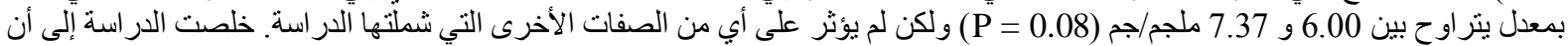

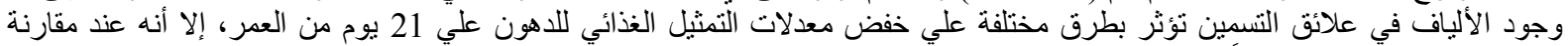

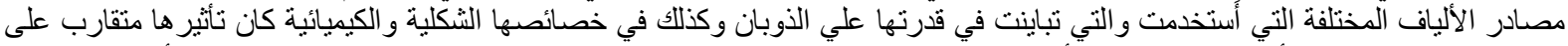

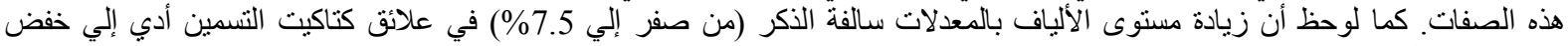
مكونات التمثيل الغذائي للاهون في الكبد علي نفس العمر. 